\title{
Microbial dynamic and growth potential of selected pathogens in Ethiopian traditional fermented beverages
}

Reda Nemo $0^{1,2}$ and Ketema Bacha ${ }^{1 *}$

\begin{abstract}
Purpose: The patterns of microbial succession and the associated physicochemical changes in the course of beverage fermentation determine the safety status of the final product against foodborne pathogens. In this study, the microbial dynamics during fermentation of three Ethiopian traditional fermented beverages (namely, borde, tej, and grawa) and the growth potential of selected foodborne pathogens in ready-to-consume beverages were assessed.
\end{abstract}

Methods: The raw materials used for lab-scale fermentation of the beverages were bought from open markets of Jimma and Anfilo towns. During fermentation, samples were drawn every $6 \mathrm{~h}$ (borde fermentation) and $12 \mathrm{~h}$ (grawa and tej fermentation). The dominant microbes of the fermentation phases were determined following standard microbiological methods. The growth potential of Escherichia coli, Salmonella typhimurium, Staphylococcus aureus, Listeria monocytogenes, and Candida albicans in the ready-to-consume beverages were assessed by microbial enumeration over defined storage period.

Result: Early fermentation period of all beverages was dominated by aerobic mesophilic bacteria, staphylococci, and Enterobacteriaceae with highest mean counts (Log CFU/ml) of $6.42 \pm 0.10,5.44 \pm 0.08$, and $5.40 \pm 0.11$, respectively. At the end of fermentation, yeast counts (Log CFU/ml) dominated in tej $(9.41 \pm 0.06)$ and grawa (7.88 $\pm 0.02)$ samples, while lactic acid bacteria dominated in borde sample $(7.33 \pm 0.07)$. During fermentation, $\mathrm{pH}$ dropped for borde ( $4.58 \pm 0.03$ to $4.22 \pm 0.01$ ), and grawa (4.18 \pm 0.10 to $3.62 \pm 0.02)$, but increased for tej (5.26 \pm 0.01 to $5.50 \pm 0.03$ ) during the first $24 \mathrm{~h}$, though it dropped later down to $3.81 \pm 0.02$ at 144 th $\mathrm{h}$. All reference pathogens were unable to reach infective dose in grawa and tej samples. However, borde sample supported their growth to infective dose within $24 \mathrm{~h}$. Thus, grawa and tej beverages had the capability of inhibiting growth of pathogens while borde needs basic safety control measures during preparation and storage.

Conclusion: With further safety evaluation of the products, the production processes of the three beverages could be scaled up for commercial purposes using defined starter cultures originated from the same beverages. However, the safety status of borde calls for further evaluation for alternative shelf-life extension mechanisms including the introduction of organic preservatives from local products such as medicinal plants.

Keywords: Beverages, Fermentation, Growth potential, Microbial dynamic, Pathogens

\footnotetext{
* Correspondence: ketemabacha2002@yahoo.com

'Department of Biology, College of Natural Sciences, Jimma University,

P.O.Box 378, Jimma, Ethiopia

Full list of author information is available at the end of the article
}

(c) The Author(s). 2021 Open Access This article is licensed under a Creative Commons Attribution 4.0 International License, which permits use, sharing, adaptation, distribution and reproduction in any medium or format, as long as you give appropriate credit to the original author(s) and the source, provide a link to the Creative Commons licence, and indicate if changes were made. The images or other third party material in this article are included in the article's Creative Commons licence, unless indicated otherwise in a credit line to the material. If material is not included in the article's Creative Commons licence and your intended use is not permitted by statutory regulation or exceeds the permitted use, you will need to obtain permission directly from the copyright holder. To view a copy of this licence, visit http://creativecommons.org/licenses/by/4.0/. 


\section{Highlights}

$\triangleright$ LAB and yeast dominated the fermentation of all local beverages.

$\triangleright$ The counts of molds, coliform, and

Enterobacteriaceae were below detectable level at the end of fermentation.

$\triangleright T$ Tej and grawa beverages did not support the growth of test pathogens but borde.

$\triangleright E$. coli and S. typhimurium showed higher survival ability than S. aureus and L. monocytogenes in grawa and tej samples.

$\triangleright$ The beverage could be source of probiotic and starter culture LAB and yeasts.

\section{Introduction}

Fermentation is a low-priced food biotechnological process being used worldwide to improve organoleptic properties, reduce toxic substances and anti-nutritional factors, and enhances the product's acceptability (Simatende et al. 2015). Originally, the production of fermented beverages was done to boost the shelf-life of perishable raw materials of agricultural and animal origin. Currently, the widely accepted concept of fermentation is the use of microorganisms and their enzymes for the production of fermented products through acidification, alcoholization, and proteolysis (Ashaolu 2019; De Roos and De Vuyst 2018).

During traditional fermentation of beverages, several groups of microorganisms are known to involve in the fermentation processes. While some microbes initiate the fermentation process, others dominate the fermentation process in succession until few strains finally takeover the remaining fermentation phases toward the end of fermentation (Kosisochukwu et al. 2020; Mulaw and Tesfaye 2017; Tsafrakidou et al. 2020). Hence, certain microorganisms initiate the fermentation and dominate for a specific period; subsequently, the number declines due to the accumulation of different metabolites and inhibitory substances produced as by-products. In this way, the fermenting microorganisms provide an appropriate and conducive environment to less sensitive species while it inhibits the sensitive pathogens through the production of inhibitory factors (Chaves-Lopez et al. 2020).

In the early stage of fermentation, aerobic mesophiles such as staphylococci, micrococci, members of Enterobacteriaceae, and Bacillus dominate fermenting beverages. In the course of fermentation, however, the most common fermenting microorganisms such as Leuconostoc, Lactobacillus, Streptococcus, Pediococcus, Micrococcus, Saccharomyces cerevisiae, Kluyvermyces bulgaricus, and Debaromyces phaffi dominate fermentation of
African indigenous beverages (Bahiru et al. 2006; Jespersen 2003; Ketema et al. 1998).

The dominant microorganisms at the end of fermentation of beverages are usually lactic acid bacteria and yeast, which resist the changes in the physicochemical properties of beverages, thus, persisting throughout fermentation (Nemo and Bacha 2020). Both LAB and yeast produce metabolites such as lactic acid, propionic acid, acetic acid, ethanol, and hydrogen peroxide, as well as other secondary metabolites/antimicrobial compounds/ which are strong inhibitory substances for microbial growth (Siedler et al. 2019). These metabolites are potentially effective in controlling microbes including fungal growth (Adebiyi et al. 2019). Due to their physicochemical characteristics, most of the high alcoholic beverages are considered microbiologically safe products, as the vegetative cells of pathogens cannot survive the high alcohol content, low $\mathrm{pH}$, high carbon dioxide, low oxygen, and secondary metabolites (Kim et al. 2014). Pathogens such as E. coli, S. typhimurium, and $L$. monocytogenes survive and grow rapidly at low alcoholic beverages while 5\% ethanol inhibits the growth and survival of the pathogens (Menz et al. 2010).

In Ethiopia, there are many traditional fermented beverages such as tej, borde, tella, shameta, buquri, korefe, keribo, siljo, and grawa (Lemi 2020; Nemo and Bacha 2020). Comprehensive data on the microbial dynamic and pattern of growth of potentially pathogenic organism in cases of contamination of the ready-to-consume beverages are scarce. Therefore, the present study aims to assess the microbial succession in the course of fermentation of borde, tej, and the newly described traditionally fermented beverage (grawa) and to evaluate the growth potential of selected pathogens in three of the fermented beverages.

\section{Materials and methods \\ Description of the study area}

The study was conducted in Jimma town located 353 $\mathrm{km}$ southwest of Addis Ababa, the capital city of Ethiopia. It is located at a latitude of about $7^{\circ} 13$ to $8^{\circ} 56$ $\mathrm{N}$ and longitudes of about $35^{\circ} 52$ to $37^{\circ} 37 \mathrm{E}$, an altitude ranging between 1720 to $2110 \mathrm{~m}$ above sea level, a mean annual rainfall of 800 to $2500 \mathrm{~mm}$, and annual temperature ranging from 7 to $30{ }^{\circ} \mathrm{C}$. The town is typically known for vending various traditional fermented beverages and foods of plants and animal sources (Nemo et al. 2017; Nemo and Bacha 2020).

\section{Sample collection and laboratory-scale preparation}

The raw materials used for the preparation of the three beverages were purchased from open markets of Jimma town (for borde and tej), and Mugi town of Anfilo District located in Qellem Wollega Zone, for grawa. All raw 
materials were transported to the Research and Postgraduate Laboratory, Department of Biology, College of Natural Sciences, Jimma University and used for laboratory-scale fermentation of the three traditionally fermented beverages for the determination of microbial succession during fermentation, and challenge testing of pathogens in the final products. Laboratory-scale preparation of the beverages was done by local brewers who had experience in preparing the selected beverages. The preparation protocol simulated the traditional technique followed by the local producers, and aseptic techniques were employed during preparation to avoid crosscontamination. The detailed flow charts of the traditional preparation techniques of the three beverages are as given below (Figs. 1, 2, 3).

\section{Preparation of borde}

Borde is prepared mainly from maize (Zea mays), barley (Hordeum vulgare), and malt. In this study, borde preparation did not use any starter culture to speed up the fermentation process either from previous fermentation (black slopes) or commercial starter culture (Fig. 1).

\section{Preparation of tej}

$T e j$, also called honey wine, is a home-processed beverage prepared from honey, water, malt, and chopped stems of hop (Rhamnus prenoides). In this study, the preparation of $t e j$ followed the simulated procedure of tej making in Jimma town (Fig. 2).

\section{Preparation of grawa}

Grawa is a fermented beverage prepared from specific honey made using flowers of Vernonia amygdalina and water from Anfilo District. Grawa from previous fermentation (back slope) has been used as a starter culture and the whole fermentation processes takes about $72 \mathrm{~h}$ (Fig. 3).

\section{Microbial dynamics}

Microbial successions in grawa, borde, and tej samples were assessed by microbiological enumeration during the $24 \mathrm{~h}$ fermentation period for borde, $72 \mathrm{~h}$ for grawa, and $144 \mathrm{~h}$ for tej. Samples were drawn at every $6 \mathrm{~h}$ gaps for borde and $12 \mathrm{~h}$ for grawa and tej. Accordingly, $10 \mathrm{ml}$ of each sample was suspended in $90 \mathrm{ml}$ of peptone water and homogenized in a flask for 10 min using a homogenizer (Edmund Buhler $\mathrm{GmbH}$, Germany) at $100 \mathrm{rpm}$. Then, $1 \mathrm{ml}$ of each sample was homogenized in $9 \mathrm{ml}$ peptone water and serially diluted up to $10^{-7}$. Finally, $0.1 \mathrm{ml}$ of aliquot was spread plated on plate count agar (PCA) for aerobic mesophilic bacteria and aerobic spore-forming bacteria (after heating the sample for $10 \mathrm{~min}$ at 80 ${ }^{\circ} \mathrm{C}$ for a count of the later), mannitol salt agar
(MSA) for staphylococci, violet red bile glucose agar (VRBGA) for Enterobacteriaceae, violet red bile agar (VRBA) for coliform, de Man Rogosa Sharpe (MRS) for lactic acid bacteria, and potato dextrose agar (PDA) supplemented with $200 \mathrm{mgL}^{-1}$ chloramphenicol for yeast and mold counts. All of the media were oxoid and incubated at $32{ }^{\circ} \mathrm{C}$ for $48 \mathrm{~h}$ for bacteria and $28{ }^{\circ} \mathrm{C}$ for $2-5$ days for yeast and mold. Moreover, the incubation condition for all microbes was aerobic except for lactic acid bacteria, which was incubated anaerobically using an anaerobic Jar (Hitech e-601, China).

\section{Physicochemical analysis during beverage fermentation pH}

$\mathrm{pH}$ was measured using a digital portal $\mathrm{pH}$ meter $(\mathrm{pH}-$ 013, China) after homogenizing $5 \mathrm{ml}$ of borde sample in $20 \mathrm{ml}$ of distilled water followed by pipetting $10 \mathrm{ml}$ of the homogenized sample into a beaker (Kebede 2007). For grawa and Tej samples, $10 \mathrm{ml}$ each was poured into a beaker and the electrode of the $\mathrm{pH}$ meter was dipped into the sample before recording the reading.

\section{Titratable acidity (TA)}

The TA of borde was determined by homogenizing 5 $\mathrm{ml}$ of borde sample in $20 \mathrm{ml}$ distilled water and filtered through Whatman no. 1 filter paper; then $9 \mathrm{ml}$ of the homogenate was pipetted into a beaker (Antony and Chandra 1997). However, for grawa and tej samples, $9 \mathrm{ml}$ of each sample was directly pipetted into a separate beaker. For all samples, 3 to 5 drops of $1 \mathrm{~g} / 100 \mathrm{ml}$ phenolphthalein indicator were added and titrated with $0.1 \mathrm{~mol} / \mathrm{L} \mathrm{NaOH}$ solution until a faint pink color persisted. The result was calculated using the following formula:

$$
\text { Lactic acid }(\mathrm{g} / 100 \mathrm{ml})=\frac{\text { Amount of } \mathrm{NaOH} \text { titrated } \times \mathrm{mol} / \mathrm{L} \text { of } \mathrm{NaOH} \times 9}{\text { The volume of sample }(\mathrm{ml})}
$$

\section{Moisture and total solid content}

Moisture content was determined by oven drying $\left(105{ }^{\circ} \mathrm{C}\right)$ of $10 \mathrm{ml}$ of the borde samples until a constant weight is persisted. Then, the moisture content was calculated by subtracting the weight of the borde sample after drying borde sample + empty crucible to constant weight divided by borde sample + empty crucible minus empty crucible times 100 (AOAC, 1990). The total solid content was determined by subtracting the moisture content from 100.

\section{Growth potential of pathogens in selected beverages}

The selected beverage samples were separately challenged with reference strains including Escherichia coli $\left(\mathrm{ATCC}^{\circ} 25922^{\mathrm{mw}}\right)$, Salmonella enterica subsp. 
One $\mathrm{kg}$ of maize (Zea mays) and $1 \mathrm{~kg}$ of white barley (Hordeum vulgare)

\section{$\downarrow$}

Grind finely

Soak in $2 \mathrm{~L}$ of water and allow staying for $12 \mathrm{~h}$

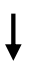

Roast in oven

Cool for 2 hrs

Cut into very small pieces using sterile knife

Weigh $1.5 \mathrm{~kg}$ of a mixture of maize and barely

Add $2 \mathrm{~L}$ of water in a plastic bucket and $0.75 \mathrm{~kg}$ of grind sun-dry maize

Mix thoroughly

Add additional $1 \mathrm{~L}$ of water and $0.75 \mathrm{~kg}$ of grind sun-dried maize (To final volume of $3 \mathrm{~L}$ )

\section{$\downarrow$}

Mix thoroughly

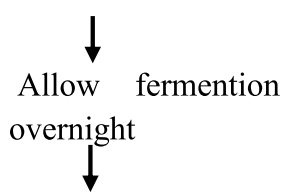

Borde
Sun-dry maize (Zea mays) seed for $5 \mathrm{hr}$

Grind finely

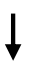

Fig. 1 Flow chart of preparation of borde (this study)

enterica serovar Typhimurium (ATCC ${ }^{\circledR} 13311^{\mathrm{TM}}$ ), Staphylococcus aureus subsp. aureus (ATCC ${ }^{\oplus} 25923^{\mathrm{TM}}$ ), Listeria monocytogenes (ATCC ${ }^{\oplus} 19115^{\mathrm{TM}}$ ), and Candida albicans $\left(\mathrm{ATCC}^{\oplus} 14053^{\mathrm{Tm}}\right.$ ) which were obtained from Ethiopian Public Health Institute (EPHI). Accordingly, $200 \mathrm{ml}$ of each beverage was separately steamed at 80 ${ }^{\circ} \mathrm{C}$ for $10 \mathrm{~min}$ to kill any vegetative cells that might be present in the beverages. Then, $100 \mathrm{ml}$ of each beverage was challenged separately with a $1 \mathrm{ml}$ overnight culture of the test strains to bring the final inoculum level to $10^{3}-10^{4} \mathrm{CFU} / \mathrm{ml}$. Then, $10 \mathrm{ml}$ of each beverage was homogenized in $90 \mathrm{ml}$ of buffered peptone water and $0.1 \mathrm{ml}$ of appropriate dilution was spread plated on eosin methylene blue agar for $E$. coli, xylose lysine deoxycholate agar for S. typhimurium, mannitol salt agar for $S$. aureus, Listeria selective agar for L. monocytogenes, and Sabouraud chloramphenicol agar for C. albicans. A portion of the beverage was further sampled aseptically at $6 \mathrm{~h}$ intervals from 0 to $24 \mathrm{~h}$ (Shamebo et al. 2016). 
Smoking of bucket jar using $2 \mathrm{~g}$ of a dried red pepper

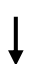

Add 3 L of tap water and $500 \mathrm{~g}$ of honey

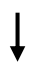

Mix thoroughly

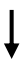

Add $100 \mathrm{~g}$ of malt (Mixture of $3 / 4$ barely and $1 / 4$ wheat) and mix. This stage is called 'birz'
Cutting hop stems to pieces red pepper

Add $270 \mathrm{~g}$ of hop stem and 1L of water into iron pot and boil until it turns red

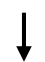

Add $100 \mathrm{~g}$ of malt and allow it to boil

Mix boiled malt and hop stem with 'birz'

Allow fermenting overnight by covering the bucket with airtight plastic<smiles>[3H][3H]</smiles>

Stir thoroughly

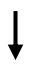

Cover the bucket jar and allow to ferment for 6 days at room temperature

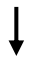

Filter through a cotton cloth to remove wax

Tej

Fig. 2 Flow chart of preparation of tej (this study)

Wash the equipment (earthen jar or Bucket) using a leaf of Vernonia $\downarrow$

Add $1.5 \mathrm{~kg}$ of honey and $5 \mathrm{~L}$ of water (Specific area)

$$
\downarrow
$$

Mix thoroughly

$\downarrow$

Add 0.5 L grawa from previous fermentation (Back slope)

$$
\downarrow
$$

Let it to ferment for $72 \mathrm{~h}$ at ambient temperature

$$
\downarrow
$$

Filter using sieve

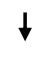

Grawa

Fig. 3 Flow chart of grawa preparation process (Nemo and Bacha 2020)

\section{Data analysis}

The colonies counted from replicate plates were calculated in $\mathrm{CFU} / \mathrm{ml}$ and later converted to $\log \mathrm{CFU} / \mathrm{ml}$. The average mean counts during microbial succession, challenge testing, and data of physicochemical parameters were tested using one-way ANOVA analysis: posthoc multiple comparisons, Tukey method, and a significant difference were considered at $P<0.05$ using SPSS version 26 .

\section{Results}

The three Ethiopian traditional fermented beverages (tej, grawa, and borde) are different in composition of ingredients used for their preparation as well as their uses. Both grawa and tej are yellow colored, had sweet taste, and used to quench thirsty and have medicinal values as used traditionally. On the other hand, borde is an opaque, effervescent, whitish-gray to brown colored beverage, commonly used to feed lactating mothers, besides its use as meal replacement 
among segement of the population who cannot afford full meal (Fig. 4).

\section{Microbial dynamics}

At the beginning of borde fermentation $(0 \mathrm{~h})$, aerobic mesophilic bacteria (AMB), staphylococci, and Enterobacteriaceae initiated the fermentation process and gradually started to dominate with counts exceeding $>5 \log$ $\mathrm{CFU} / \mathrm{ml}$. The AMB was continued to dominant until $6 \mathrm{~h}$ of fermentation with a significant difference $(p<0.05)$ in count from $0 \mathrm{~h}$. At $12 \mathrm{~h}$, and thereafter until the end of fermentation, LAB and yeast dominated the fermentation and reached the maximum counts of $7.33 \pm 0.07$ and $6.91 \pm 0.04 \log \mathrm{CFU} / \mathrm{ml}$, respectively. Similarly, in grawa beverage, at $0 \mathrm{~h}$ the count of AMB was higher $(5.06 \pm 0.02 \log \mathrm{CFU} / \mathrm{ml})$ than other microorganisms. The dominance of AMB was continued until $24 \mathrm{~h}$, and after $24 \mathrm{~h}$, the yeast and LAB dominated the fermentation process until the end of fermentation $(72 \mathrm{~h})$ and reached the maximum counts of $(7.88 \pm 0.02$ and $7.64 \pm$ $0.04 \mathrm{Log} \mathrm{CFU} / \mathrm{ml}$, respectively). Likewise, in tej fermentation, the counts of AMB until $36 \mathrm{~h}$, staphylococci, and ASFB until $24 \mathrm{~h}$ increased by more than $1 \log \mathrm{CFU} / \mathrm{ml}$ and later dropped down with a significant difference $(P$ $<0.05)$. However, the count of yeast was increased by greater than $5 \log (4.16 \pm 0.04$ to $9.41 \pm 0.06 \log \mathrm{CFU} /$ $\mathrm{ml})$ and LAB was increased by nearly $5 \log (4.01 \pm 0.03$ to $8.88 \pm 0.01 \log \mathrm{CFU} / \mathrm{ml}$ ) with a significant difference in counts between fermentation hours analyzed from the beginning $(0 \mathrm{~h})$ to the end of fermentation time (144 h). In all three beverages, the counts of molds from the beginning of fermentation, and counts of coliform, and Enterobacteriaceae after a certain time were recorded as less than $2 \log \mathrm{CFU} / \mathrm{ml}$ (Table 1 ).
In general, the counts of AMB showed a significant difference until $12 \mathrm{~h}$ for borde and grawa samples, and $24 \mathrm{~h}$ for tej sample. However, the counts of staphylococci showed no significant difference until $2 \mathrm{~h}$ for grawa and $6 \mathrm{~h}$ for borde. The counts of LAB and yeast showed significant difference in almost all the three beverage samples (Table 1).

\section{Physico-chemical changes during beverage fermentations} During microbial succession, the $\mathrm{pH}$ values of borde and grawa samples were dropped from $4.58 \pm 0.03$ to $4.22 \pm$ 0.01 and $4.18 \pm 0.10$ to $3.62 \pm 0.02$, respectively, from the beginning to the end of fermentation time. However, the $\mathrm{pH}$ of $t e j$ increased for the first $24 \mathrm{~h}$ and dropped thereafter to a minimum of $3.81 \pm 0.02$ at $144 \mathrm{~h}$. The titratable acidity and moisture content of the beverages were increased as fermentation time increased, while the total solid content was decreased. On the other hand, in borde and grawa samples, there was no significant difference $(P>0.05)$ in changes in $\mathrm{pH}$ from 0 to $6 \mathrm{~h}$ and 0 to $12 \mathrm{~h}$, respectively. Moreover, there was also no significant difference $(p<0.05)$ in titratable acidity of borde from 0 to $6 \mathrm{~h}$ of fermentation, and tej from 0 to $24 \mathrm{~h}$ of fermentation. However, there was a significant difference in titratable acidity in most fermentation times (Table 2).

\section{Growth potential of pathogens in selected beverages}

In a microbial challenge test of borde sample, the counts of all pathogens were increased significantly until the end of the challenge test. However, the rate of growth varied whereby the counts of $E$. coli $(3.15 \pm 0.03$ to 5.82 $\pm 0.08 \log \mathrm{CFU} / \mathrm{ml})$ and $S$. aureus $(3.72 \pm 0.05$ to 6.05 $\log \mathrm{CFU} / \mathrm{ml}$ ) increased by more than $2.3 \log \mathrm{CFU} / \mathrm{ml}$

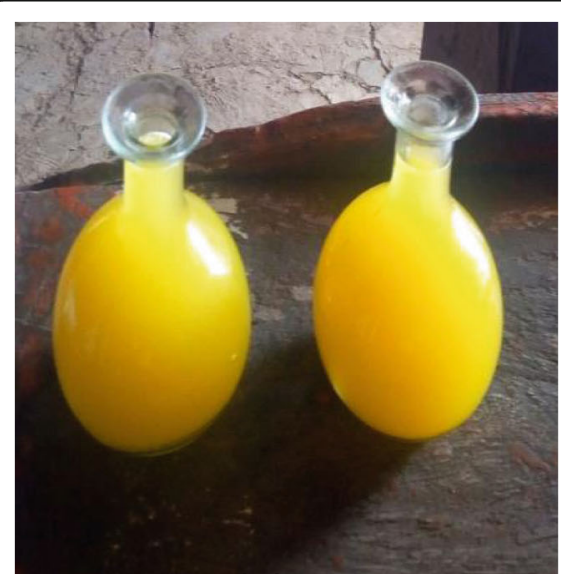

(a)

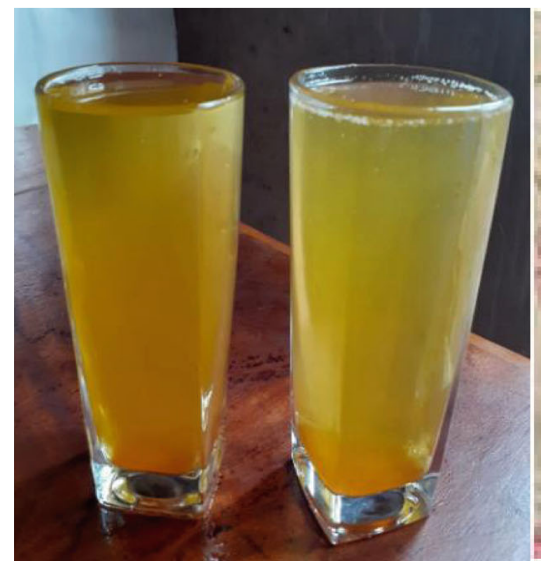

(b)

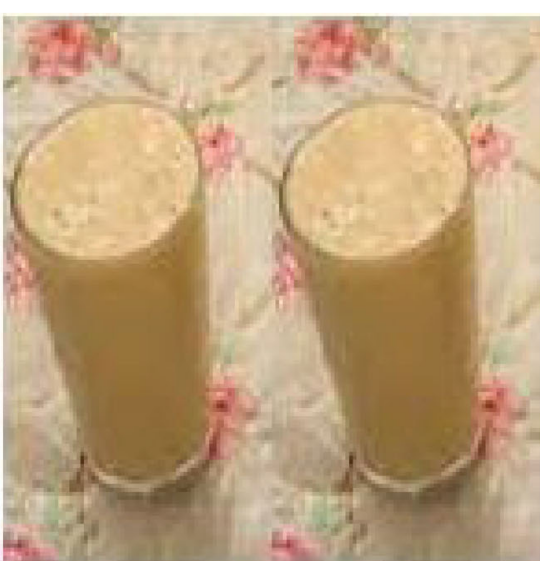

(c)

Fig. 4 Pictures of Ethiopian traditional fermented beverages: tej (a), grawa (b), and borde (c). Tej is prepared from honey, water, malt, and chopped stems of hop (Rhamnus prenoides), while grawa is made from only honey and water of Qellem Wollega Zone, Anfilo District. Borde is usually made from maize (Zea mays) and wheat (Triticum spp.) 
Table 1 Microbial dynamics (mean \pm SD) during fermentation of selected Ethiopian traditional fermented beverages

\begin{tabular}{|c|c|c|c|c|c|c|c|c|}
\hline \multirow[t]{2}{*}{ Beverages } & \multirow{2}{*}{$\begin{array}{l}\text { Fermentation } \\
\text { time }(\mathrm{h})\end{array}$} & \multicolumn{7}{|c|}{ Mean microbial count (Log CFU/ml) } \\
\hline & & AMB & Staphylococci & Enterobacteriaceae & Coliform & ASFB & LAB & Yeast \\
\hline \multirow[t]{5}{*}{ Borde } & 0 & $6.42 \pm 0.10^{\mathrm{a}}$ & $5.44 \pm 0.08^{\mathrm{a}}$ & $5.40 \pm 0.11^{\mathrm{a}}$ & $3.35 \pm 0.07^{\mathrm{a}}$ & $4.45 \pm 0.06^{\mathrm{a}}$ & $4.75 \pm 0.04^{d}$ & $4.12 \pm 0.16^{c}$ \\
\hline & 6 & $6.15 \pm 0.05^{\mathrm{b}}$ & $5.29 \pm 0.06^{\mathrm{a}}$ & $4.17 \pm 0.07^{b}$ & $2.60 \pm 0.11^{b}$ & $4.26 \pm 0.04^{\mathrm{a}}$ & $5.34 \pm 0.01^{c}$ & $4.45 \pm 0.30^{c}$ \\
\hline & 12 & $5.20 \pm 0.02^{c}$ & $4.87 \pm 0.01^{b}$ & $3.85 \pm 0.09^{c}$ & $<2$ & $4.04 \pm 0.06^{b}$ & $5.55 \pm 0.14^{c}$ & $5.22 \pm 0.09^{b}$ \\
\hline & 18 & $5.10 \pm 0.01^{c}$ & $4.15 \pm 0.05^{c}$ & $<2$ & $<2$ & $3.98 \pm 0.05^{b c}$ & $6.09 \pm 0.04^{b}$ & $5.86 \pm 0.06^{b}$ \\
\hline & 24 & $4.99 \pm 0.06^{c}$ & $3.85 \pm 0.09^{d}$ & $<2$ & $<2$ & $3.77 \pm 0.11^{c}$ & $7.33 \pm 0.07^{\mathrm{a}}$ & $6.91 \pm 0.04^{a}$ \\
\hline \multirow[t]{7}{*}{ Grawa } & 0 & $5.06 \pm 0.02^{c}$ & $4.91 \pm 0.06^{\mathrm{a}}$ & $4.29 \pm 0.06^{c}$ & $4.13 \pm 0.03^{\mathrm{a}}$ & $3.89 \pm 0.06^{b}$ & $4.63 \pm 0.03^{e}$ & $4.73 \pm 0.02^{e}$ \\
\hline & 12 & $6.30 \pm 0.12^{\mathrm{a}}$ & $5.14 \pm 0.01^{\mathrm{a}}$ & $5.16 \pm 0.04^{a}$ & $4.11 \pm 0.03^{\mathrm{a}}$ & $4.56 \pm 0.14^{\mathrm{a}}$ & $5.70 \pm 0.02^{d}$ & $5.40 \pm 0.08^{d}$ \\
\hline & 24 & $6.41 \pm 0.04^{\mathrm{a}}$ & $5.08 \pm 0.09^{a}$ & $4.73 \pm 0.06^{b}$ & $4.08 \pm 0.06^{\mathrm{a}}$ & $4.51 \pm 0.01^{\mathrm{a}}$ & $6.26 \pm 0.09^{c}$ & $6.06 \pm 0.08^{c}$ \\
\hline & 36 & $5.54 \pm 0.05^{b}$ & $4.37 \pm 0.04^{b}$ & $3.61 \pm 0.08^{d}$ & $3.03 \pm 0.02^{b}$ & $4.49 \pm 0.01^{a}$ & $6.49 \pm 0.03^{b}$ & $6.39 \pm 0.06^{b c}$ \\
\hline & 48 & $4.73 \pm 0.14^{d}$ & $3.95 \pm 0.14^{c}$ & $2.80 \pm 0.02^{\mathrm{e}}$ & $2.21 \pm 0.13^{c}$ & $3.39 \pm 0.08^{c}$ & $6.45 \pm 0.01 b^{c}$ & $6.67 \pm 0.16^{b}$ \\
\hline & 60 & $3.82 \pm 0.05^{e}$ & $3.62 \pm 0.07^{d}$ & $<2$ & $<2$ & $3.06 \pm 0.08^{d}$ & $7.46 \pm 0.09^{a}$ & $7.71 \pm 0.09^{a}$ \\
\hline & 72 & $3.39 \pm 0.02^{f}$ & $2.77 \pm 0.01^{e}$ & $<2$ & $<2$ & $2.58 \pm 0.03^{e}$ & $7.64 \pm 0.04^{a}$ & $7.88 \pm 0.02^{a}$ \\
\hline \multirow[t]{13}{*}{ Tej } & 0 & $5.37 \pm 0.04^{c}$ & $3.90 \pm 0.02^{d}$ & $4.34 \pm 0.07^{c}$ & $3.23 \pm 0.02^{c}$ & $4.13 \pm 0.02^{c}$ & $4.01 \pm 0.03^{k}$ & $4.16 \pm 0.04^{i}$ \\
\hline & 12 & $5.94 \pm 0.04^{b}$ & $4.73 \pm 0.01^{b}$ & $4.70 \pm 0.06^{b}$ & $3.55 \pm 0.01^{\mathrm{a}}$ & $4.25 \pm 0.01^{b c}$ & $4.83 \pm 0.06^{j}$ & $4.97 \pm 0.04^{h}$ \\
\hline & 24 & $6.58 \pm 0.02^{\mathrm{a}}$ & $5.63 \pm 0.11^{\mathrm{a}}$ & $5.17 \pm 0.07^{a}$ & $3.51 \pm 0.08^{\mathrm{ab}}$ & $5.42 \pm 0.01^{\mathrm{a}}$ & $5.53 \pm 0.13^{i}$ & $5.39 \pm 0.07^{9}$ \\
\hline & 36 & $6.62 \pm 0.01^{a}$ & $4.41 \pm 0.03^{c}$ & $4.26 \pm 0.04^{c}$ & $3.38 \pm 0.07^{b}$ & $4.36 \pm 0.03^{b}$ & $5.94 \pm 0.03^{h}$ & $6.62 \pm 0.07^{f}$ \\
\hline & 48 & $6.36 \pm 0.16^{a}$ & $4.31 \pm 0.02^{c}$ & $3.82 \pm 0.06^{d}$ & $3.15 \pm 0.04^{c}$ & $4.17 \pm 0.10^{c}$ & $6.60 \pm 0.08^{9}$ & $6.77 \pm 0.01^{f}$ \\
\hline & 60 & $5.41 \pm 0.09^{c}$ & $4.05 \pm 0.08^{d}$ & $3.28 \pm 0.08^{e}$ & $2.83 \pm 0.03^{d}$ & $3.83 \pm 0.06^{d}$ & $6.65 \pm 0.04^{9}$ & $6.84 \pm 0.06^{f}$ \\
\hline & 72 & $5.29 \pm 0.08^{c}$ & $3.93 \pm 0.02^{d}$ & $3.13 \pm 0.01^{\mathrm{ef}}$ & $<2$ & $3.21 \pm 0.01^{e}$ & $7.10 \pm 0.03^{f}$ & $7.40 \pm 0.05^{e}$ \\
\hline & 84 & $4.60 \pm 0.10^{d}$ & $3.22 \pm 0.02^{\mathrm{e}}$ & $3.01 \pm 0.04^{f}$ & $<2$ & $3.14 \pm 0.01^{e}$ & $7.51 \pm 0.07^{e}$ & $7.53 \pm 0.04^{e}$ \\
\hline & 96 & $4.28 \pm 0.21^{d}$ & $2.77 \pm 0.01^{f}$ & $2.55 \pm 0.17^{9}$ & $<2$ & $2.83 \pm 0.05^{f}$ & $7.84 \pm 0.07^{d}$ & $8.43 \pm 0.06^{d}$ \\
\hline & 108 & $3.64 \pm 0.04^{e}$ & $2.55 \pm 0.01^{9}$ & $<2$ & $<2$ & $2.69 \pm 0.07^{f g}$ & $8.15 \pm 0.06^{c}$ & $8.61 \pm 0.07^{c d}$ \\
\hline & 120 & $3.52 \pm 0.04^{\mathrm{e}}$ & $2.34 \pm 0.02^{h}$ & $<2$ & $<2$ & $2.51 \pm 0.07^{g h}$ & $8.41 \pm 0.08^{b c}$ & $8.76 \pm 0.11^{c}$ \\
\hline & 132 & $3.45 \pm 0.03^{e}$ & $2.13 \pm 0.01^{i}$ & $<2$ & $<2$ & $2.34 \pm 0.01^{\mathrm{hi}}$ & $8.62 \pm 0.08^{\mathrm{ab}}$ & $9.01 \pm 0.04^{b}$ \\
\hline & 144 & $3.42 \pm 0.01^{e}$ & $2.07 \pm 0.06^{i}$ & $<2$ & $<2$ & $2.22 \pm 0.02^{i}$ & $8.88 \pm 0.01^{a}$ & $9.41 \pm 0.06^{a}$ \\
\hline
\end{tabular}

$A M B$ aerobic mesophilic bacteria, $A S F B$ aerobic spore forming bacteria, $L A B$ lactic acid bacteria

Evaluation of the microbial dynamics was conducted following the traditional fermentation techniques and their respective duration of fermentation: $24 \mathrm{~h}$ for borde (sampling every $6 \mathrm{~h}$ ), $72 \mathrm{~h}$ of fermentation for grawa, and $144 \mathrm{~h}$ for tej (sampling every $12 \mathrm{~h}$ ). The patterns of microbial dynamics of the three beverages were presented with mean microbial counts (mean \pm SD of Log CFU/ml). The statistical analysis was determined by one-way ANOVA with Tukey post hoc test. Different letters in superscript along a column indicate a significant difference $(p<0.05)$, the same letters indicate no significant difference $(p>0.05)$

while S. typhimurium $(3.48 \pm 0.04$ to $5.44 \pm 0.01 \mathrm{log}$ $\mathrm{CFU} / \mathrm{ml}$ ) and C. albicans (3.57 \pm 0.07 to $5.09 \pm 0.09 \log$ $\mathrm{CFU} / \mathrm{ml}$ ) increased by less than $2 \log \mathrm{CFU} / \mathrm{ml}$ (Fig. $5 \mathrm{~A})$. In the grawa sample, fast reduction $(0.52 \log )$ of $L$. monocytogenes was observed from the initial $0 \mathrm{~h}(3.90 \pm$ $0.02 \mathrm{CFU} / \mathrm{ml})$ to $6 \mathrm{~h}(3.38 \pm 0.03 \mathrm{log} \mathrm{CFU} / \mathrm{ml})$ with a significant difference $(p<0.05)$ between counts, while $S$. typhimurium and E. coli were reduced by $0.1 \log$ with no significant difference $(p>0.05)$ between counts of different sampling hours. At the end of microbial challenge testing, E. coli, S. typhimurium, S. aureus, and $L$. monocytogenes were reduced by $>1 \log$ unit. However, C. albicans was reduced by $0.7 \log$ (Fig. 5B). Moreover, in tej sample, C. albicans was reduced to a lesser extent (0.88 $\mathrm{CFU} / \mathrm{ml})$ when compared to other pathogens. However, L. monocytogenes were highly reduced (2.2 $\mathrm{CFU} / \mathrm{ml}$ ) with a significant difference (Fig. 5C) among counts. The $\mathrm{pH}$ in all samples drawn during the challenge test did show no remarkable difference.

\section{Discussion}

During the fermentation of borde, early hours of fermentation were dominated by AMB, staphylococci, Enterobacteriaceae, and ASFB. However, at the end of fermentation LAB and yeast dominated the fermentation and reached the maximum count of $7.33 \pm 0.07$ and $6.91 \pm 0.04$, respectively. In line with the present study, Kosisochukwu et al. (2020) reported that microbes such as Streptococcus, Bacillus, and Corynebacterium started the fermentation which were later dominated by LAB and yeast during ogi fermentation (usually produced from the fermentation of maize or other cereals). Similarly, Ketema et al. (1998) reported that the onset of fermentation of borde was dominated by staphylococci, Bacillus, and members of Enterobacteriaceae. In a related 
Table 2 Some physicochemical characteristics (mean \pm SD) during laboratory-scale fermentation of selected beverages

\begin{tabular}{|c|c|c|c|c|c|}
\hline Sample & Fermentation time (h) & $\mathrm{pH}$ & Titratable acid & Moisture content $(\mathrm{g} / 100 \mathrm{ml})$ & Total solid content $(\mathrm{g} / 100 \mathrm{ml})$ \\
\hline \multirow[t]{5}{*}{ Borde } & 0 & $4.58 \pm 0.03^{\mathrm{a}}$ & $0.17 \pm 0.02^{d}$ & $74.17 \pm 0.75^{d}$ & $25.83 \pm 0.75^{a}$ \\
\hline & 6 & $4.55 \pm 0.02^{\mathrm{a}}$ & $0.21 \pm 0.01^{d}$ & $76.65 \pm 0.48^{c}$ & $23.35 \pm 0.48^{b}$ \\
\hline & 12 & $4.31 \pm 0.01^{b}$ & $0.25 \pm 0.02^{c}$ & $77.59 \pm 0.04^{b c}$ & $22.41 \pm 0.04^{b c}$ \\
\hline & 18 & $4.27 \pm 0.02^{\mathrm{bc}}$ & $0.32 \pm 0.01^{b}$ & $78.48 \pm 0.36^{b}$ & $22.41 \pm 0.36^{c}$ \\
\hline & 24 & $4.22 \pm 0.01^{c}$ & $0.40 \pm 0.02^{\mathrm{a}}$ & $82.79 \pm 0.83^{a}$ & $21.52 \pm 0.83^{d}$ \\
\hline \multirow[t]{7}{*}{ Grawa } & 0 & $4.18 \pm 0.10^{\mathrm{a}}$ & $0.19 \pm 0.02^{f}$ & $85.57 \pm 0.08^{d}$ & $14.43 \pm 0.08^{\mathrm{a}}$ \\
\hline & 12 & $4.16 \pm 0.06^{\mathrm{a}}$ & $0.22 \pm 0.01^{\text {ef }}$ & $85.71 \pm 0.03^{d}$ & $14.29 \pm 0.03^{\mathrm{a}}$ \\
\hline & 24 & $4.11 \pm 0.08^{\mathrm{ab}}$ & $0.25 \pm 0.02^{\text {de }}$ & $85.92 \pm 0.20^{c d}$ & $14.08 \pm 0.20^{\mathrm{ab}}$ \\
\hline & 36 & $3.96 \pm 0.03^{b c}$ & $0.29 \pm 0.01^{\mathrm{cd}}$ & $85.94 \pm 0.21^{\mathrm{cd}}$ & $14.06 \pm 0.21^{\mathrm{ab}}$ \\
\hline & 48 & $3.90 \pm 0.02^{\mathrm{cd}}$ & $0.33 \pm 0.02^{c}$ & $86.32 \pm 0.21^{c}$ & $13.68 \pm 0.21^{b}$ \\
\hline & 60 & $3.76 \pm 0.02^{\mathrm{de}}$ & $0.57 \pm 0.03^{b}$ & $88.15 \pm 0.32^{b}$ & $11.85 \pm 0.32^{c}$ \\
\hline & 72 & $3.62 \pm 0.02^{e}$ & $0.83 \pm 0.08^{\mathrm{a}}$ & $89.96 \pm 0.28^{a}$ & $10.04 \pm 0.28^{d}$ \\
\hline \multirow[t]{13}{*}{ Tej } & 0 & $5.26 \pm 0.01^{c}$ & $0.13 \pm 0.01^{h}$ & $74.28 \pm 0.58^{k}$ & $25.72 \pm 0.58^{a}$ \\
\hline & 12 & $5.36 \pm 0.02^{b}$ & $0.15 \pm 0.01^{h}$ & $75.36 \pm 0.23^{k}$ & $24.64 \pm 0.23^{a}$ \\
\hline & 24 & $5.50 \pm 0.03^{a}$ & $0.12 \pm 0.01^{h}$ & $76.83 \pm 0.24^{j}$ & $23.17 \pm 0.24^{b}$ \\
\hline & 36 & $4.85 \pm 0.01^{d}$ & $0.23 \pm 0.01^{9}$ & $77.11 \pm 0.56^{i j}$ & $22.89 \pm 0.56^{b c}$ \\
\hline & 48 & $4.58 \pm 0.02^{\mathrm{e}}$ & $0.27 \pm 0.03^{9}$ & $78.01 \pm 0.21^{\mathrm{hi}}$ & $21.90 \pm 0.21^{\mathrm{cd}}$ \\
\hline & 60 & $4.27 \pm 0.03^{f}$ & $0.34 \pm 0.04^{f}$ & $78.82 \pm 0.20^{g h}$ & $21.18 \pm 0.20^{\text {de }}$ \\
\hline & 72 & $4.19 \pm 0.01^{9}$ & $0.38 \pm 0.02^{\text {ef }}$ & $79.51 \pm 0.16^{\mathrm{fg}}$ & $20.49 \pm 0.16^{\mathrm{ef}}$ \\
\hline & 84 & $4.14 \pm 0.02^{g h}$ & $0.39 \pm 0.04^{\mathrm{ef}}$ & $80.56 \pm 0.59^{e f}$ & $19.44 \pm 0.59^{f g}$ \\
\hline & 96 & $4.11 \pm 0.01^{\mathrm{hi}}$ & $0.42 \pm 0.03^{\mathrm{de}}$ & $81.44 \pm 0.29^{e}$ & $18.56 \pm 0.29^{9}$ \\
\hline & 108 & $4.05 \pm 0.04^{i}$ & $0.46 \pm 0.01^{\mathrm{cd}}$ & $83.18 \pm 0.64^{d}$ & $16.82 \pm 0.64^{h}$ \\
\hline & 120 & $3.94 \pm 0.05^{j}$ & $0.49 \pm 0.01^{b c}$ & $84.93 \pm 0.25^{c}$ & $15.07 \pm 0.25^{i}$ \\
\hline & 132 & $3.85 \pm 0.01^{k}$ & $0.54 \pm 0.01^{\mathrm{ab}}$ & $86.89 \pm 0.29^{b}$ & $13.11 \pm 0.29^{j}$ \\
\hline & 144 & $3.81 \pm 0.02^{k}$ & $0.58 \pm 0.01^{\mathrm{a}}$ & $88.76 \pm 0.22^{a}$ & $11.24 \pm 0.22^{k}$ \\
\hline
\end{tabular}

The physicochemical characteristics of the fermented beverages were assessed based on the beverages fermentation times: 24,72 , and $144 \mathrm{~h}$ for borde, tej, and grawa, respectively. The mean \pm standard is presented and the statistical analysis was determined by one-way ANOVA with Tukey post hoc test. Different letters in superscript along a column indicate a significant difference $(p<0.05)$, the same letters indicate no significant difference $(p>0.05)$

development, Nemo and Bacha (2020) reported maximum count of LAB and yeast at the level of $6.87 \pm 0.67$ and $6.56 \pm$ $0.81 \mathrm{CFU} / \mathrm{ml}$, respectively, from borde samples collected from Jimma and Danaba towns. The dominance of Enterobacteriaceae in early fermentation initiate the fermentation by utilizing simple sugars produced after the action of amylase from malt and amylolytic microorganisms and produce some basic vitamins used by fermentative microorganisms (LAB and yeast) for the production of organic acids, flavor compounds, peptides, ethanol, and aroma compounds (Ewuoso et al. 2020; Ketema et al. 1998). On the other hand, the presence of some aerobic spore-forming bacteria (Bacillus spp.) secrete a wide range of degradative enzymes, such as amylases and proteases, and thus playing an important role in sustaining the supply of simple sugars for fermentation processes to continue (Almeida et al. 2007).

At the end of the fermentation of grawa, the counts of yeast and LAB reached the maximum counts $(7.88 \pm$ 0.02 and $7.64 \pm 0.04 \log \mathrm{CFU} / \mathrm{ml}$, respectively). In higher counts to the present study, Nemo and Bacha (2020) reported $8.43 \pm 0.72 \log \mathrm{CFU} / \mathrm{ml}$ of yeast and $8.13 \pm 0.67$ $\log \mathrm{CFU} / \mathrm{ml}$ of LAB from grawa beverage collected from Anfilo District of Qellem Wollega Zone, Southwest Ethiopia. The lower count of yeast and LAB in the present study could be due to environmental factors. Even though the production process followed was similar during grawa fermentation, environmental conditions such as temperature and moisture content could lead to vibrant differences in the kinetics and the product besides the microbial profile of the final product (Kirchmayr et al. 2017).

During tej fermentation, the counts of AMB, staphylococci, and ASFB were increased significantly $(p<0.05)$ in the first $24 \mathrm{~h}$ and later dropped. However, the counts of yeast and LAB continuously increased until the end of fermentation and reached the maximum counts of 9.41 \pm 0.06 and $8.88 \pm 0.01 \log \mathrm{CFU} / \mathrm{ml}$, respectively. This report was much higher than the report by Nemo and 

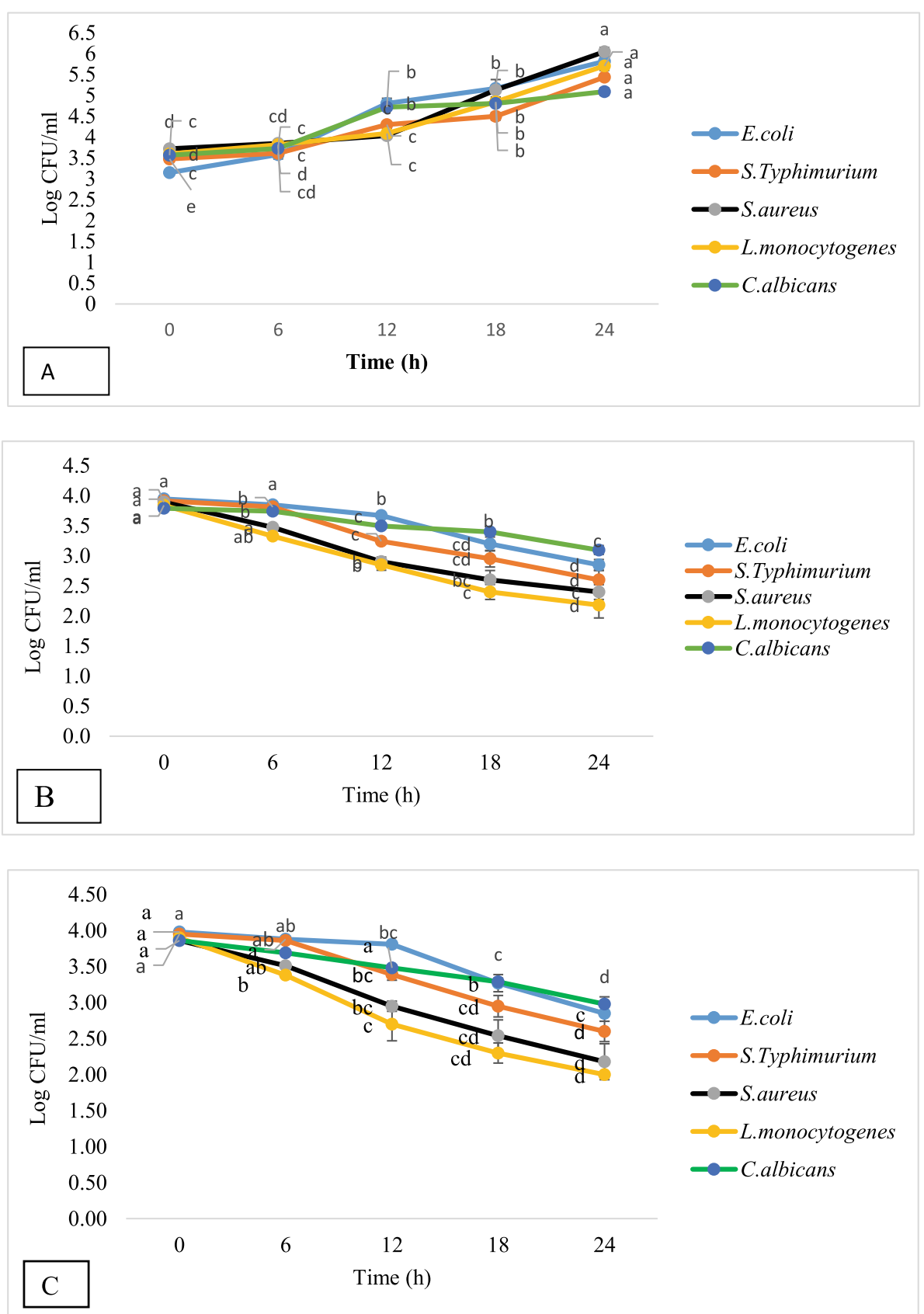

Fig. 5 Growth potential of pathogens in borde (A), grawa (B), and tej (C) beverages. The growth potential of E. coli, S. typhimurium, S. aureus, L. monocytogenes, and $\mathrm{C}$. albicans in the three beverages was assessed within $24 \mathrm{~h}$ by drawing samples at an interval of 6 h. The growth or no growth of these pathogens was determined having cultured the drawn samples on the pathogens' respective media, incubated at $37^{\circ} \mathrm{C}$, and counted viable cells which latter expressed in Log CFU/ml. The mean \pm standard is presented and the statistical analysis was determined using one-way ANOVA with Tukey post hoc test. Different letters in superscript along a column indicate presence of significant difference $(p<0.05)$, while the same letters indicate absence of significant difference $(p>0.05)$

Bacha (2020), who reported $6.31 \pm 0.63$ and $6.09 \pm 0.53$ $\log \mathrm{CFU} / \mathrm{ml}$ from Jimma town $t e j$ vendors. And report by Bahiru et al. (2006) who reported yeast and lactic acid flora counts $(<7 \log \mathrm{CFU} / \mathrm{ml})$ of tej from an indigenous Ethiopian honey wine. The increment of counts observed during the first $24 \mathrm{~h}$ dropped later due to $\mathrm{pH}$ change (increased in the first $24 \mathrm{~h}$ and dropped later). Moreover, the observed higher count of yeast and LAB could likely be due to appropriate utilization of raw materials or ingredients (honey, wheat, and barley) without adulterating. Mostly, the local tej retailer uses sugar commercially produced in industries instead of using 
honey as raw materials mainly because the honey price is getting expensive.

In tej fermentation, the presence highest counts of yeast and LAB co-existed was originated from the raw materials: honey, malt, and hops. In traditional fermented beverages, the source of microorganisms involved in the fermentation processes predominantly originates from microflora naturally present in the substrates and utensils/ equipment used for fermentation. During fermentation, microbial group coexisting together to enhance the fermentation processes by adapting to the changing intrinsic and extrinsic conditions caused by the physicochemical changes associated with microbial activity, duration of fermentation, temperature, and moisture content (Navarrete-bola 2012; Tamang et al. 2016).

In general, locally consumed beverages usually use rudimentary materials for preparation, and hence the microbial succession in due course of fermentation usually depends on the physicochemical characteristics of the fermenting matrix. Accordingly, the physicochemical properties of the selected beverages investigated in the current study showed a significant difference $(p<0.05)$ in their physicochemical properties from the initial fermentation hours to the end of fermentation. Specifically, there was a reduction of $\mathrm{pH}$ in tej $(5.26 \pm 0.01$ to $3.81 \pm 0.02)$, borde $(4.58 \pm 0.03$ to $4.22 \pm 0.01)$, and grawa $(4.18 \pm 0.10$ to $3.62 \pm 0.02)$ at the end of the fermentation while titratable acidity increased. The reduction in $\mathrm{pH}$ during fermentation time is accounted to change in an organic substrate to different end-products mainly organic acids esters and carbonyls by the action of the dominant microbes like LAB and yeast (Peyer et al. 2016). Titratable acidities increased significantly with days of fermentation in association with the accumulation of dominant metabolites such as lactic acid and acetic acid as opposed to a decline in $\mathrm{pH}$ (Liang et al. 2020).

In the present study, there was an increment of moisture contents $(\mathrm{g} / 100 \mathrm{ml})$ in all samples; borde $(74.17 \pm$ 0.75 to $82.79 \pm 0.83)$, grawa $(85.57 \pm 0.08$ to $89.96 \pm$ $0.28)$, and tej (74.28 \pm 0.58 to $88.76 \pm 0.22)$. The highest moisture content $(\mathrm{g} / 100 \mathrm{ml})$ at the end of fermentation was lower than the report of Nemo and Bacha (2020), who reported $87.29 \pm 3.21$ in borde, $95.84 \pm 1.10$ in grawa, and $95.78 \pm 1.21$ in tej. The increase in the moisture content can be attributed to the addition of water to the substrate before fermentation (Ekundayo et al. 2013). The increment of moisture content with fermentation time is the consumption of dry matter and water production during aerobic and anaerobic catabolism by yeasts and lactic acid bacteria (Laetitia et al. 2005).

Microbiological challenge testing is a valuable approach to determine a food or beverage ability to support the growth of the specific pathogens. In the present study, the growth of all reference pathogens in two beverages (grawa and tej) was gradually reduced and survived for only certain periods. The $\mathrm{pH}$, alcoholic content, secondary metabolites of LAB, and yeast could be the main factors that are responsible for the reduction of pathogens inoculated for the beverages. The $\mathrm{pH}$ of grawa and tej in the present study was less than 4 until the end of the challenge test. Fermented alcoholic beverages contain valuable nutrients that have health benefits and are mostly acknowledged as microbiologically safe due to their high ethanol content greater than $4 \%$ and low pH (less than 4.5) (Jeon et al. 2015). According to the Nemo and Bacha (2020) report, grawa and tej had low $\mathrm{pH}(<4)$ and higher alcoholic content $(>4 \%)$. Occasionally, pathogens can survive extremely low $\mathrm{pH}$ $(<4.00)$ for a certain time by pumping out of protons, production of ammonia, and proton-consuming through processes of decarboxylation of carboxyl groups of amino acids of proteins source reaction and the $\mathrm{pH}$ value 4.0-5.0 can support growth (Lund et al. 2014; Vivijs et al. 2016).

In this study, E. coli and S. typhimurium showed higher survival ability than S. aureus and L. monocytogenes in grawa and tej samples. Moreover, C. albicans were more resistant than all pathogens challenged. The better survival ability of Gram-negative bacteria than Gram-positive could be due to the cell-free supernatant of LAB and the ability to respond to stress. Cell-free supernatant of LAB has good antimicrobial properties against Gram-positive or closely related microorganisms than Gram-negative (MoraVillalobos et al. 2020). E. coli is capable of producing stress response mechanisms that facilitate its adaptation to acid tolerance, which provides more resistance in acidic environments (Chauret 2011). C. albicans has an extraordinary capacity to alter extracellular $\mathrm{pH}$, creating a neutral environment from either acidic or alkaline starting conditions, with changes in the $\mathrm{pH}$ units when glucose is repressible and requires exogenous amino acids (Vylkova 2017).

In the current study, all pathogens reach the infective dose in borde beverage. Borde supported the growth of pathogens due to low alcoholic content, less acidic (4.22) due to the short fermentation time of the beverages (an overnight fermentation), and has a good nutritional profile for the proliferation of microorganisms. Foodborne pathogens like E. coli O157:H7, Staphylococcus aureus, Shigella flexneri, and Salmonella spp. can survive and grow in fermenting borde (Tadesse et al. 2005). According to Nemo and Bacha (2020) report, borde has low alcoholic content, good nutritional value with relatively high $\mathrm{pH}$ that supports the growth of some undesired microorganisms. 


\section{Conclusion}

The selected beverages fermentation process was initiated by AMB, Enterobacteriaceae, staphylococci, and ASFB, and later due to the changes in physicochemical properties, $\mathrm{LAB}$ and yeast (the most fermentative and less affected by physicochemical changes) dominated the fermentation. The higher counts of LAB and yeast in tej were a potential source for industrial purposes: enzymes, ethanol, and organic acids production. In the microbial challenge testing, all reference strains challenged into tej and grawa samples showed a gradual reduction. Among the strains, $E$. coli had the highest resistance next to $C$. albicans in two alcoholic beverages. Hence, the survival ability of the pathogens in alcoholic and low $\mathrm{pH}$ beverages (grawa and tej) was very low. Moreover, borde (the low alcoholic beverage) supports the growth of pathogens and cause health risks unless care is taken after preparation.

\section{Acknowledgements}

The authors would like to thank Jimma University, College of Natural Sciences for funding, Department of Biology, Oromia Educational Bureau, and Dambi Dollo College of Teachers Education for facilitating the study.

\section{Authors' contributions}

RN: Conceptualization, designing, validation, formal analysis, investigation, resources, data curation, writing-original draft. KB: Conceptualization, designing, validation, formal analysis, writing — review and editing, supervision, project administration, and fund acquisition. The authors read and approved the final manuscript.

\section{Funding}

The research was financially supported by Jimma University, College of Natural Sciences.

\section{Availability of data and materials}

All data supporting the results are included in the article.

\section{Declarations}

Ethics approval and consent to participate

NA.

\section{Consent for publication}

NA.

\section{Competing interests}

The authors declare that they have no conflict of interest.

\section{Author details}

'Department of Biology, College of Natural Sciences, Jimma University, P.O.Box 378, Jimma, Ethiopia. ${ }^{2}$ Dambi Dollo College of Teachers Education, Dambi Dollo, Ethiopia.

Received: 2 April 2021 Accepted: 18 May 2021

Published online: 28 May 2021

\section{References}

Adebiyi JA, Kayitesi E, Adebo OA, Changwa R, Njobeh PB (2019) Food fermentation and mycotoxin detoxification: an African perspective. Food Control 106:106731. https://doi.org/10.1016/j.foodcont.2019.106731

Almeida EG, Rachid CC, Schwan RF (2007) Microbial population present in fermented beverage ' cauim ' produced by Brazilian Amerindians. Int J Food Microbiol 120(1-2):146-151. https://doi.org/10.1016/j.jifoodmicro.2007.06.020
Antony U, Chandra TS (1997) Microbial population and biochemical changes in fermenting finger millet (Eleusine coracana). World J Microbiol Biotechnol 13(5):533-537. https://doi.org/10.1023/A:1018561224777

AOAC (1990) Official methods of analysis, vol 1, 15th edn. Herich. Ked. Association of Official Analytical Chemists, Arlington

Ashaolu TJ (2019) A review on selection of fermentative microorganisms for functional foods and beverages: the production and future perspectives. Int J Food Sci Technol 54(8):1-9. https://doi.org/10.1111/ijfs.14181

Bahiru B, Mehari T, Ashenafi M (2006) Yeast and lactic acid flora of tej , an indigenous Ethiopian honey wine: variations within and between production units. Food Microbiol 23(3):277-282. https://doi.org/10.1016/j.fm.2005.05.007

Chauret C (2011) Survival and control of Escherichia coli O157:H7 in foods, beverages, soil and water. Virulence 2(6):593-601. https://doi.org/10.4161/ viru.2.6.18423

Chaves-Lopez C, Rossi C, Maggio F, Paparella A (2020) Changes occurring in spontaneous maize fermentation: an overview. Fermentation Rev 6(1):36. https://doi.org/10.3390/fermentation6010036

De Roos J, De Vuyst L (2018) Acetic acid bacteria in fermented foods and beverages. Curr Opin Biotechnol 49:115-119. https://doi.org/10.1016/j. copbio.2017.08.007

Ekundayo FO, Oladipupo OA, Ekundayo EA (2013) Studies on the effects of microbial fermentation on bush mango (Irvingia gabonensis ) seed cotyledons. Afr J Microbiol Res 7:4363-4367. https://doi.org/10.5897/A JMR12.1800

Ewuoso MO, Animashaun $\mathrm{OH}$, Adejumo AA (2020) Lactic acid bacteria and yeasts in spontaneously fermented sorghum sourdough. Am J Microb Res 8:63-72. https://doi.org/10.12691/ajmr-8-2-4

Jeon S, Kim N, Shim M, Jeon Y, Ahn J, Lee SH, Hwang IG, Rhee M (2015) Microbiological diversity and prevalence of spoilage and pathogenic bacteria in commercial fermented alcoholic beverages (beer, fruit wine, refined rice wine, and yakju). J Food Prot 78(4):812-818. https://doi.org/10.4315/0362-02 8X.JFP-14-431

Jespersen $L$ (2003) Occurrence and taxonomic characteristics of strains of Saccharomyces cerevisiae predominant in African indigenous fermented foods and beverages. Fed Eur Microbio/ Soc 3:191-200. https://doi.org/10.101 6/S1567-1356(02)00185-X

Kebede A (2007) Isolation, characterization and identification of lactic acid bacteria involved in traditional fermentation of borde, an Ethiopian cereal beverage. Afr J Biotechnol 6:1469-1478

Ketema B, Tetemke M, Mogessie A (1998) The microbial dynamics of "Borde" fermentation, a traditional Ethiopian fermented beverage. SINET:Ethiop.J.Sci 21(2):195-205. https://doi.org/10.4314/sinet.v21i2.18120

Kim SA, Kim NH, Lee SH, Hwang IG, Rhee MS (2014) Survival of foodborne pathogenic bacteria (Bacillus cereus, Escherichia coli O157: H7, Salmonella enterica Serovar Typhimurium, Staphylococcus aureus, and Listeria monocytogens). J Food Prot 77(3):419-426. https://doi.org/10.4315/0362-028X JFP-13-234

Kirchmayr MR, Segura-garcía LE, Lappe-oliveras P (2017) Impact of environmental conditions and process modifications on microbial diversity, fermentation efficiency, and chemical profile during the fermentation of Mezcal in Oaxaca. LWT Food Sci Technol 79:160-169. https://doi.org/10.1016/j.lwt.2016.12.052

Kosisochukwu C, Iyeoma F, Nkemjika G (2020) Microbial succession pattern in Ogi fermentation international journal of advanced research in biological sciences microbial succession pattern in Ogi fermentation. Int J Adv Res Biol Sci 5:1-6. https://doi.org/10.22192/ijarbs

Laetitia M, Joseph HD, Joseph D (2005) Physical, chemical and microbiological changes during natural fermentation of "gowé", a sprouted or non sprouted sorghum beverage from West-Africa. Afr J Biotechnol 4:487-496

Lemi BW (2020) Microbiology of Ethiopian traditionally fermented. Int J Agric Food Sci. https://doi.org/10.1155/2020/1478536

Liang Z, Lin X, He Z, Li W, Ren X, Lin X (2020) Dynamic changes of total acid and bacterial communities during the traditional fermentation of Hong Qu glutinous rice wine. Electron J Biotechnol 43:23-31. https://doi.org/10.1016/j. ejbt.2019.12.002

Lund P, Tramonti A, Biase D (2014) Coping with low pH: molecular strategies in neutralophilic bacteria. Fed Eur Microbiol Soc 38(6):1091-1125. https://doi. org/10.1111/1574-6976.12076

Menz G, Vriesekoop F, Zarei M, Zhu B, Aldred P (2010) International journal of food microbiology the growth and survival of food-borne pathogens in sweet and fermenting brewers' wort. Int J Food Microbiol 140(1):19-25. https://doi.org/10.1016/j.jifoodmicro.2010.02.018 
Mora-Villalobos JA, Montero-Zamora J, Barboza N, Carolina R-G, Usaga J, Redondo-Solano M, Schroedter L, Olszewska-Widdrat A, López-Gómez JP (2020) Multi-product lactic acid bacteria fermentations. Fermentation Rev 6(1):23. https://doi.org/10.3390/fermentation6010023

Mulaw G, Tesfaye A (2017) Technology and microbiology of traditionally fermented food and beverage products of Ethiopia: a review. Afr J Microbiol Res Rev 11:825-844. https://doi.org/10.5897/AJMR2017.8524

Navarrete-bola L (2012) Improving traditional fermented beverages: how to evolve from spontaneous improving traditional fermented beverages: how to evolve from spontaneous to directed fermentation. Eng Life Sci 12(4):410418. https://doi.org/10.1002/elsc.201100128

Nemo R, Bacha K (2020) Microbial, physicochemical and proximate analysis of selected Ethiopian traditional fermented beverages. LWT Food Sci Technol 131:109713. https://doi.org/10.1016/j.lwt.2020.109713

Nemo R, Bacha K, Ketema T (2017) Microbiological quality and safety of somestreet- vended foods in Jimma town, southwestern Ethiopia. Afr J Microbiol Res 11(14):574-585. https://doi.org/10.5897/AJMR2014.7326

Peyer LC, Zannini E, Arendt EK (2016) Lactic acid bacteria as sensory biomodulators for fermented cereal-based beverages trends in food science \& technology lactic acid bacteria as sensory biomodulators for fermented cereal- based beverages. Trends Food Sci Technol 54:17-25. https://doi.org/1 0.1016/j.tifs.2016.05.009

Shamebo T, Bacha K, Ketema T (2016) The growth potential and antimicrobial susceptibility patterns of salmonella species and Staphylococcus aureus isolated from mobile phones of food handlers and health care workers in Jimma town , Southwest Ethiopia. Afr J Microbiol Res 10(8):254-259. https:// doi.org/10.5897/AJMR2015.7621

Siedler S, Balti R, Neves AR (2019) Bioprotective mechanisms of lactic acid bacteria against fungal spoilage of food. Curr Opin Biotechnol 56:138-146. https://doi.org/10.1016/j.copbio.2018.11.015

Simatende P, Henry T, Jabulani S (2015) Methods of preparation of Swazi traditional fermented foods. J Ethnic Foods J 2(3):119-125. https://doi.org/1 0.1016/j.jef.2015.08.008

Tadesse G, Ashenafi M, Ephraim E (2005) Survival of E. coli O157: H7 Staphylococcus aureus, Shigella flexneri and salmonella spp . In fermenting Ô Borde ', a traditional Ethiopian beverage. Food Control 16(2):189-196. https:// doi.org/10.1016/j.foodcont.2004.01.011

Tamang JP, Watanabe K, Holzapfel WH (2016) Review: diversity of microorganisms in global fermented foods and beverages. Front Microbiol 7 : 377. https://doi.org/10.3389/fmicb.2016.00377

Tsafrakidou P, Michaelidou A-M, Biliaderis C (2020) Fermented cereal-based products: nutritional aspects, possible impact on gut microbiota and. Foods Rev 9(6):734. https://doi.org/10.3390/foods9060734

Vivijs B, Aertsen A, Michiels CW (2016) Identification of genes required for growth of Escherichia coli MG1655 at moderately low pH. Front Microbiol 7:1-14. https://doi.org/10.3389/fmicb.2016.01672

Vylkova S (2017) Environmental pH modulation by pathogenic fungi as a strategy to conquer the host. PLoS Pathog 13(2):1-6. https://doi.org/10.1371/journal. ppat.1006149

\section{Publisher's Note}

Springer Nature remains neutral with regard to jurisdictional claims in published maps and institutional affiliations.

Ready to submit your research? Choose BMC and benefit from:

- fast, convenient online submission

- thorough peer review by experienced researchers in your field

- rapid publication on acceptance

- support for research data, including large and complex data types

- gold Open Access which fosters wider collaboration and increased citations

- maximum visibility for your research: over $100 \mathrm{M}$ website views per year

At BMC, research is always in progress.

Learn more biomedcentral.com/submissions 